\title{
Why two torture committees?
}

\author{
Bent Sørensen Copenhagen, Denmark
}

\begin{tabular}{|c|c|c|}
\hline \multicolumn{3}{|c|}{ TABLE 1} \\
\hline & CAT & $\mathrm{CPT}$ \\
\hline Definition of torture & yes & no \\
\hline $\begin{array}{l}\text { Receives and treats complaints } \\
\text { about individuals }\end{array}$ & yes & no \\
\hline Punishes torturers & yes & no \\
\hline Requests education & yes & yes $^{\star}$ \\
\hline Requests rehabilitation & yes & yes $^{\star}$ \\
\hline Meetings & public & in camera \\
\hline
\end{tabular}

^Not mentioned in the text of the convention, but suggestions can be put forward in the report to the state.

CAT, the Committee Against Torture, is the United Nations executive organ for the Convention of 10th December 1984 against Torture and Other Cruel, Inhuman or Degrading Treatment or Punishment, which came into force in June 1987, when 20 nations had ratified. By the end of 1990,51 out of a total of 161 states had ratified. The committee consists of 10 members. All continents are represented. Most members are from the legal profession - law professors, judges, prison governors. Until April 1991 there was only one practising doctor, myself; however, since April the representation of the medical profession has been strengthened, as was desirable, with the member from The Philippines being replaced by a professor of psychiatry.

The committee can receive and treat complaints of torture, both from individuals and from organisations - the Convention contains a definition of torture. The complaints are dealt with in closed meetings. The number of complaints has been very modest during the first three years the committee has existed - less than 10. The committee uses almost all of its working-time in receiving, discussing, criticising and commenting on the initial reports which must be delivered by all the states, which have ratified the convention and on reports every four years thereafter. The reports must describe thoroughly how the state in question has implemented the Convention through legislation and what measures the state has taken to ensure that the rules of the Convention are observed, including those concerning education and rehabilitation. The reports from the states are made public, and the negotiations take place in open meetings, in the presence of many NGOs (non-governmental organisations), but seldom with the press present.

The committee draws up a yearly report for the General Assembly of the United Nations, which gives a careful account of the statements from the various states and the committee's comments.

CPT, the Committee for the Prevention of Torture, is the Council of Europe's Committee for The European Convention for the Prevention of Torture and Inhuman or Degrading Treatment or Punishment, (the working language is English or French).

This convention came into force on February 1, 1989 , when seven states had ratified. The CPT started its work on November 13,1989 and is thus only one and a half years old. In January 199120 out of 24 states had ratified.

The CPT consists of one member per country. 
However, the member does not represent that country, but must be 'of high moral character - known for competence in the field of human rights or having professional experience ... They shall be independent, impartial and available'. For the moment the CPT has four members from the medical profession, along with law professors, one judge, members with backgrounds from within the prison system and politicians.

The CPT makes inspections of institutions in which people are held against their will, such as prisons, police stations, refugee camps, closed psychiatric departments and the like.

After the inspection a report is prepared, possibly with suggestions for improvements, and the report is forwarded to the state in question.

The European convention does not contain any definition of torture or degrading or inhuman treatment. The CPT sets its own limits.

All meetings of the CPT are closed (in camera, Article 6), and on the whole the CPT's work is based on co-operation (Article 3) and confidentiality (Article 11).

The characteristic features of the CAT and the CPT are outlined in Table 1.

Thus, the work of the two committees is not identical and does not much overlap. The two committees supplement each other and used in the right way they constitute very efficient weapons in the fight against, and prevention of, torture.

Professor Bent Sørensen, MD, DMSc, is a member of the United Nations Committee Against Torture (CAT) and $\vec{\exists}$ First Vice-President of the Council of Europe's Committee for the Prevention of Torture (CPT). 